\title{
ANALISIS PENGARUH PERTUMBUHAN EKONOMI, PENGELUARAN PEMERINTAH DAN INFLASI TERHADAP INVESTASI DI SUMATERA BARAT
}

\author{
ANALYSIS OF THE EFFECT OF ECONOMIC GROWTH, GOVERNMENT \\ EKSPENDITURE AND INFLATION ON WEST SUMATERA INVESTMENT
}

\author{
Novera Martilova dan Amsah Hendri Doni \\ Fakultas Ekonomi dan Bisnis Islam IAIN Bukittinggi \\ Jl. Raya Gurun Aur Kecamatan Banuhampu Kabupaten Agam \\ noveramartilova@yahoo.co.id, amsahsmart@yahoo.co.id
}

Naskah diterima 21 Mei 2020, di-review 05 Juni 2020, disetujui 30 Juni 2020

\begin{abstract}
This research aims to analyze the effect of Economic Growth, Government Expenditures and Inflation on Investment in West Sumatra from 2001-2015. The type of this research is descriptive and associative; the data analyses used are descriptive analysis and inductive analysis. The analysis model used is the Ordinary Last Square (OLS) Method. The results of the study concluded that (1) Economic growth has a significantly positive effect on investment in West Sumatra. (2) Government Expenditures have a significant positive effect on Investment in West Sumatra. (3) Inflation has a negative significant effect on investment in West Sumatra. (4) Simultaneously, Economic Growth, Government Expenditures and Inflation have a significant effect on Investment in West Sumatra at 97.8\% for the period of 2001-2015.
\end{abstract}

Keyword: Investment, Economic Growth, Government Expenditure and Inflation

\begin{abstract}
Abstrak: Penelitian ini bertujuan untuk menganalisis pengaruh Pertumbuhan Ekonomi, Pengeluaran Pemerintah dan Inflasi terhadap Investasi di Sumatera Barat periode 2001-2015. Jenis penelitian ini adalah deskriptif dan asosiatif dan analisis data yang digunakan adalah analisis deskriptif dan analisis induktif. Model analisis yang digunakan adalah Metode Ordinary Last Square (OLS). Hasil penelitian menyimpulkan bahwa (1) Pertumbuhan Ekonomi berpengaruh signifikan secara positif terhadap Investasi di Sumatera Barat. (2) Pengeluaran Pemerintah berpengaruh signifikan secara positif terhadap Investasi di Sumatera Barat. (3) Inflasi berpengaruh signifikan secara negatif terhadap Investasi di Sumatera Barat. (4) Secara Simultan Pertumbuhan Ekonomi, Pengeluaran Pemerintah dan Inflasi berpengaruh signifikan terhadap Investasi di Sumatera Barat sebesar 97,8 \% periode 2001-2015.
\end{abstract}

Kata Kunci: Investasi, Pertumbuhan Ekonomi, Pengeluaran pemerintah dan Inflasi.

\section{PENDAHULUAN}

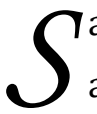
alah satu fundamental makroekonomi adalah investasi. Peningkatan kapasitas produksi salah satunya disebabkan oleh peningkatan investasi di sisi lain. Oleh karena itu peningkatan kapasitas produksi berimplikasi pada peningkatan output dan pada gilirannya meningkatkan perekonomian (Rahardja). Hal ini berarti peningkatan output adalah konsekuensi logis dari adanya investasi yang menstimulus terciptanya barang modal baru.

Makmun \& Yasin (2003) menyebutkan bahwa kata kunci dari penentu tingkat investasi adalah Pertumbuhan Ekonomi yang meningkat dan stabil. Selain dari gambaran kenaikan output secara signifikan, juga memperlihatkan peningkatan 
total investasi. "Sedangkan pada sisi Pengeluaran Pemerintah melalui pengeluaran rutin dan pengeluaran pembangunan memberikan pengaruh berupa peningkatan penerimaan masyarakatmelalui efek pelipatgandaan (Multiplier effect) (Boediono, 1999)".Jadi dengan adanya peningkatan pendapatan otomatis berpengaruh terhadap tabungan dan konsumsi masyarakat dan pada gilirannya akan berdampak peningkatan pada permintaan secara agregat. Dengan begitu investasi produsen dalam rangka memperluas kapastas produksi akan dirangsang oleh peningkatan permintaan.

Selain itu investasi juga dipengaruhi secara negatif oleh inflasi. Pernyataan ini dapat dijelaskan bahwa kondisi inflasi yang tinggi selalu memberikan risiko atas proyek-proyek investasi yang ada dan rata-rata masa jatuh tempo pinjaman sebuah modal akan berkurang dalam waktu jangka panjang. Disamping itu, "tingkat inflasi yang tinggi sering dinyatakan sebagai ukuran ketidakstabilan roda ekonomi dan kegagalan pemerintah dalam membuat paket kebijakan secara makro (Rahardja, 2014)."

Pada tabel 1 dapat dilihat bahwa perkembangan investasi, Pertumbuhan Ekonomi yang diproksikan pada PDRB, dan inflasi di Sumbar dari tahun 2001-2015 mengalami fluktuasi. Terlihat PDRB pada tahun 2011 mengalami kenaikan dari 5,96\% menjadi 6,24\%, sedangkan investasi di tahun 2011 mengalami tren penurunan dari 11,20\% menjadi 1,52\%. Jadi dari kondisi ini dapat disimpulkan bahwa tidak adanya hubungan yang positif antara Pertumbuhan Ekonomi dengan investasi, walaupun secara nominal sama-sama mengalami kenaikan.

Tabel 1: Investasi, Pertumbuhan Ekonomi, Pengeluaran Pemerintah dan Inflasi di Sumatera BaratTahun 2001-2015

\begin{tabular}{|c|c|c|c|c|c|c|c|c|}
\hline \multirow{2}{*}{ Tahun } & \multicolumn{2}{|c|}{ Investasi } & \multicolumn{2}{|c|}{ PDRB } & \multicolumn{2}{|c|}{$\begin{array}{c}\text { Pengeluaran } \\
\text { Pemerintah }\end{array}$} & \multicolumn{2}{|c|}{ Inflasi } \\
\hline & Milyar Rp & $\%$ & Milyar Rp & $\%$ & Milyar Rp & $\%$ & (\%) & $\%$ \\
\hline 2001 & 4.736 .135 & - & 23.727.373 & - & 3.186.193 & - & 9,86 & - \\
\hline 2002 & 4.785 .540 & 1,04 & 24.840 .188 & 4,69 & 3.196.461 & 0,32 & 10,22 & 3,65 \\
\hline 2003 & 4.934 .281 & 3,11 & 26.146.781 & 5,26 & 3.282.956 & 2,71 & 5,55 & $-45,69$ \\
\hline 2004 & 5.091 .190 & 3,18 & 27.578.137 & 5,47 & 3.354 .525 & 2,18 & 6,98 & 25,77 \\
\hline 2005 & 5.388 .134 & 5,83 & 29.159.481 & 5,73 & 3.496 .421 & 4,23 & 20,47 & 193,27 \\
\hline 2006 & 5.604 .646 & 4,02 & 30.949 .395 & 6,14 & 3.658.087 & 4,62 & 8,05 & $-60,67$ \\
\hline 2007 & 5.824 .273 & 3,92 & 32.912 .970 & 6,34 & 3.829.041 & 4,67 & 6,90 & $-14,29$ \\
\hline 2008 & 6.112 .929 & 4,96 & 35.007 .922 & 6,37 & 4.020 .199 & 4,99 & 12,68 & 83,77 \\
\hline 2009 & 6.569 .621 & 7,47 & 36.683 .239 & 4,79 & 4.316.785 & 7,38 & 2,05 & $-83,83$ \\
\hline 2010 & 6.643 .190 & 11,20 & 38.869 .164 & 5,96 & 5.016 .264 & 16,20 & 7,84 & 282,44 \\
\hline 2011 & 6.743 .839 & 1,52 & 41.293 .349 & 6,24 & 5.609 .534 & 11,83 & 5,37 & $-31,51$ \\
\hline 2012 & 6.836 .128 & 1,37 & 43.925 .820 & 6,38 & 5.999 .081 & 6,94 & 4,16 & $-22,53$ \\
\hline 2013 & 7.009 .882 & 2,54 & 46.640 .235 & 6,18 & 6.374 .377 & 6,26 & 10,87 & 161,30 \\
\hline 2014 & 7.262 .589 & 3,61 & 49.365 .753 & 5,84 & 6.749.092 & 5,88 & 11,58 & 6,53 \\
\hline 2015 & 7.322.483 & 0,82 & 50.821 .678 & 2,95 & 6.937.245 & 2,79 & 10,76 & $-7,08$ \\
\hline
\end{tabular}

Sumber: BPS dan BAPPEDA Provinsi Sumatera Barat 2017, Data Diolah 
Sementara perkembangan dari sisi Pengeluaran Pemerintah, pada tahun 2013 perkembangan Pengeluaran Pemerintah mengalami penurunan dari $6,94 \%$ menjadi $6,26 \%$,sedangkan perkembangan investasi mengalami kenaikan dari 1,37\% menjadi 2,54\%. Hal ini juga menunjukkan bahwa Pengeluaran Pemerintah dan investasi tidak memiliki hubungan yang positif. Dari sisi inflasi juga dapat dilihat pada tahun 2010, perkembangan inflasi meningkat tajam dari $-83,83 \%$ menjadi $282,44 \%$, diikuti investasi yang mengalami peningkatan dari $7,47 \%$ menjadi $11,20 \%$. Hal ini berarti inflasi dan investasi tidak memiliki hubungan negatif.

\section{KERANGKA KONSEPTUAL}

\section{Teori Investasi}

Investasi dalam teori ekonomi memiliki arti sejumlah modal berupa uang yang digunakan untuk membeli alat-alat produksi termasuk barang-barang yang akan dijual nantinya (Winardi, 1992). Sedangkan secara makro, investasi adalah penambahan stok modal guna untuk kebutuhan belanja pada sektor bisnis dalam satu periode tertentu (Nanga, 2005)."

Adapun menurut Halim (2005:1), investasi adalah keuntungan yang akan diperoleh sebagai implikasi dari kebijakan penambahan sejumlah dana. Berdasarkan jenisnya investasi dibagi menjadi dua, yaitu investasi negara (investasi pihak pemerintah) dan investasi swasta (investasi pihak swasta). Kemudian pada perkembangannya kedua jenis investasi ini terdapat pula investasi asing oleh pihak pemerintah asing maupun swasta asing (Winardi, 1992).
Kemudian investasi memiliki dua tujuan utama yakni untuk mengganti bahagian dari penyediaan modal yang tidak dapat dipakai lagi atau yang dapat diperbaiki (depresiasi) dan tambahan atas penyediaan modal yang ada (investasi netto).

\section{Teori Pertumbuhan Ekonomi}

Pertumbuhan Ekonomi (economic growth) secara paling sederhana dapat diartikan sebagai akumulasi pendapatan nasional secara agregat dalam kurun waktu tertentu (Prasetyo, 2011). Perekonomian sebuah negara dikatakan mengalami pertumbuhan apabila balas jasa riil terhadap penggunaan faktor-faktor produksi pada tahun sebelumnya tidak lebih besar dari tahun saat ini. Berdasarkan hal itu, Pertumbuhan Ekonomi dapat diartikan sebagai peningkatan kapasitas produksi barang dan jasa secara fisik dalam dari waktu ke-waktu.

Sukirno (2010) mengungkapkan bahwa suatu perekonomian dapat dikategorikan tumbuh apabila output perkapita mengalami kenaikan dalam waktu jangka panjang. Pertumbuhan Ekonomi juga dapat dijadikan sebagai suatu ukuran kuantitatif yang mengdeskripsikan perkembangan suatu perekonomian dalam satu tahun tertentu apabila dibandingkan dengan tahun sebelumnya. Sedangkan Arsyad (2010) mendefinisikan Pertumbuhan Ekonomi sebagai suatu proses penambahan pendapatan riil per kapita penduduk suatu negara dalam jangka panjang.

\section{Teori Pengeluaran Pemerintah}

Pengeluaran Pemerintah merupakan kebijakan yang menghasilkan output guna Analisis Pengaruh Pertumbuhan Ekonomi... || 23 
untuk kepentingan hajat hidup orang banyak. Kebijakan ini dapat berupa pembelian barang dan jasa dari sejumlah biaya yang telah dianggarkan (Mangkosoebroto, 2001: 169).

Pengeluaran Pemerintah merupakan kegiatan rutin setiap tahun dalam rangka menyusun alokasi anggaran dalam bentuk Anggaran Pendapatan dan Belanja Negara (APBN) untuk nantinya direalisasikan ke pelbagai sektor atau bidang dengan tujuan untuk kesejahteraan rakyat. Dalam Anggaran Pendapatan dan Belanja Negara (APBN) terdapat dua jenis Pengeluaran Pemerintah Indonesia yaitu:

\section{Pengeluaran Rutin}

Pengeluaran rutin merupakan sejumlah biaya yang timbul dari penyelenggaraan dan pemeliharaan roda pemerintahan, seperti dari belanja pegawai (gaji pokok dan tunjangan), belanja barang, subsidi, pembayaran angsuran dan bunga utang negara, belanja pemeliharaan dan belanja perjalanan.

2. Pengeluaran Pembangunan

Pengeluaran pembangunan merupakan penambahan modal masyarakat melalui pembangunan fisik dan non. Contoh: pembangunan jalan, jembatan, sekolah dan ruman sakit. Sedangkan pembangunan non fisik seperti pelaksanaan program pengentasan kemiskinan."

\section{Teori Inflasi}

Inflasi merupakan peristiwa yang lazim terjadi dalam sebuah perekonomian. Sukirno (2010: 302) menyebutkan bahwa inflasi selalu ditandai dengan kenaikan harga harga yang berlaku. Sedangkan sejumlah presentasi atas kenaikan harga-harga barang dalam periode waktu tertentu disebut dengan tingkat inflasi. Kisaran tingkat inflasi yang lazim terjadi adalah sebesar 2 sampai 4 persen per-tahun, inflasi ini dikelompokkan sebagai inflasi merayap. Bahkan kisaran inflasi dapat mencapai angka antara 5 hingga 10 persen pertahun, inflasi jenis ini tergolong dalam inflasi yang lebih serius. Dalam kondisi tertentu, inflasi juga dapat mencapai ratusan bahkan ribuan persen pertahun sebagai akibat dari resesi ekonomi atau sebab-sebab lain, inflasi ini tergolong dalam inflasi hiper.

\section{METODE PENELITIAN}

\section{Jenis Penelitian}

Jenis penelitian ini digolongkan penelitian deskriptif dan asosiatif. Metode deskriptif adalah penelitian yang berusaha untuk menuturkan pemecahan masalah yang ada sekarang berdasarkan data-data yang berarti juga menyajikan data, menganalisis dan menginterpretasikan. Sedangkan penelitian asosiatif adalah penelitian yang menguji ada tidaknya hubungan atau pengaruh antara satu variabel dengan variabel lainnya.

\section{Tempat dan Waktu Penelitian}

Lokasi penelitian dilakukan di Sumatera Barat. Dengan mengamati beberapa faktor yang dapat memberi pengaruh terhadap naik turunnya perkembangan investasi di Sumatera Barat, namun belum diketahui seberapa besar pengaruh faktor-faktor tersebut terhadap naik turunnya perkembangan investasi di Sumatera Barat. Penelitian dilakukan dengan pengambilan data yang diperoleh dari badan pusat statistik Sumatera Barat.

\section{$24 \|$ Novera Martilova, Amsah Hendri Doni}




\section{Jenis dan Sumber Data}

Jenis data yang digunakan serta diolah dalam penelitian ini adalah data sekunder, yaitu data yang diperoleh dari beberapa sumber. Data di ambil selama periode 2001-2015. Data diperoleh dalam bentuk time series. Data yang dikumpulkan berupa data investasi, pertumbuhan penduduk, inflasi, produk domestik regional bruto (PDRB), dan pengeluaran pemerintah, di Sumatera Barat periode 2001-2015. Data-data tersebut diperoleh dari Badan pusat statistik (BPS) Sumatera barat, jurnal-jurnal, artikel-artikel, serta buku-buku yang mempunyai keterkaitan dengan masalah yang dibahas dalam penelitian ini yang diperoleh dari perpustakaan.

\section{Teknik Pengumpulan Data}

Teknik pengumpulan data adalah cara yang digunakan untuk memperoleh data penelitian.
Data yang digunakan dalam penelitian ini adalah data sekunder yang diperoleh dari lembaga atau instansi yang terkait seperti laporan bulanan dan laporan tahunanBadan Pusat Statistik (BPS) berbagai edisi.

\section{Teknik Analisis Data}

1. Uji Asumsi Klasik

2. Uji Regresi Linear berganda

3. Uji Koefisien Determinan

4. Uji Hipotesis

\section{PEMBAHASAN DAN HASIL}

\section{Uji Asumsi klasik}

Hasil uji asumsi klasik dapat kita lihat pada table dengan rincian sebagai berikut:

Tabel 2. Hasil Durbin Watson

\begin{tabular}{|l|l|l|}
\hline \multicolumn{1}{|c|}{ Model } & \multicolumn{1}{|c|}{ Koefisien Durbin Watson } & \multicolumn{1}{c|}{ Keterangan } \\
\hline 1 & 1,869 & Tidak ada autokorelasi \\
\hline
\end{tabular}

Sumber: Data diolah tahun 2018

Pada tabel 3 dapat diketahui bahwa baik independen atau tidak ada autokorelasi yang secara negatif maupun positif tidak ditemukan ditunjukan dengan nilai koefisien Durbin Watson autokorelasi sehingga variabel tersebut yaitu 1,869.

Tabel 3. Hasil Uji Multikolinearitas

\begin{tabular}{|c|c|c|c|}
\hline \multirow{2}{*}{$\begin{array}{c}\text { Model } \\
\text { (Constant) }\end{array}$} & \multicolumn{2}{|c|}{ Collinearity Statistic } & \multirow{2}{*}{ Keterangan } \\
\hline & Tolerance & VIF & \\
\hline $\begin{array}{l}\text { Pertumbuhan Ekonomi }\left(X_{1}\right) \\
\text { Pengeluaran Pemerintah }\left(X_{2}\right) \\
\text { Inflasi }\left(X_{3}\right)\end{array}$ & $\begin{array}{l}0,333 \\
0,375 \\
0,981 \\
\end{array}$ & $\begin{array}{l}3,327 \\
3,319 \\
1,019 \\
\end{array}$ & $\begin{array}{l}\text { Tidak ada Multi } \\
\text { Tidak ada Multi } \\
\text { Tidak ada Multi }\end{array}$ \\
\hline
\end{tabular}

Sumber: Data diolah tahun 2018

Multikolinearitas terjadi apabila korelasi antar variabel bebas memiliki nilai VIF $\geq 5$, kemudian apabila nilai VIF-nya $<5$, maka dapat disimpulkan bahwa multikolinearitas tidak terjadi pada $\alpha 5 \%$, maka didapat hasil korelasi antara variabel bebas sebagaimana dilihat pada Tabel diatas. Dari Tabel 4 dapat dilihat nilai $X_{1}=3,327, X_{2}=3,319$ dan $X_{3}=1,019$. Maka dapat diperoleh kesimpulan bahwa tidak adanya multikolinearitas pada variabel bebas, sebab nilai 
VIF $<5$, sehingga semua variabel bebas yakni dan inflasi dapat dimasukan pada model regresi Pertumbuhan Ekonomi, Pengeluaran Pemerintah, penelitian ini

Tabel 4. Hasil Uji Normalitas dengan One-Sample Kolmogrov-Smirnov

\begin{tabular}{|l|l|l|}
\hline & & \multicolumn{1}{|c|}{ Unstandardized Residual } \\
\hline \multirow{N}{*}{ Normal Parameters ${ }^{\mathrm{a}, \mathrm{b}}$} & & 15 \\
\hline & Mean & .0000000 \\
\cline { 2 - 3 } & Std.Deviation & 1.35754000 \\
\hline & Absolute & .155 \\
\hline & Positive & .155 \\
\hline Kolmogrov-Smirnov Z & Negative & -.115 \\
\hline Asymp.Sig.(2-tailed) & & .599 \\
\hline
\end{tabular}

Sumber: Data diolah tahun 2018

Data yang terdistribusi secara normal maka data tersebut dikategorikan sebagai data yang baik. Data yang terdistribusi secara normal memiliki karakteristik dengan nilai sig $>\alpha 0,05$ dan distribusi tidak normal jika nilaisig $<\alpha 0,05$. Berdasarkan pengolahan data yang dilakukan dengan metode One-Sample Kolmogrov-Smirnov pada aplikasi SPSS, diperoleh hasil bahwa data yang dipakai pada penelitian ini adalah normal. Karena nilai sig $>\alpha$ $(0,05)$ yaitu sebesar $(0.866>0.05)$.

\section{Analisis Regresi Linear Berganda}

Analisis yang digunakan pada model penelitian ini adalah analisis regresi linear berganda. Analisis ini dilakukan untuk mengetahui pengaruh antara variabel bebas terhadap variabel terikat. Berdasarkan hasil penelitian dapat diperoleh pengaruh Pertumbuhan Ekonomi, Pengeluaran Pemerintah dan Inflasi terhadap Investasi di Provinsi Sumatera Barat yang disajikan pada Tabel 6.

Tabel 5. Hasil Olahan Data Regresi Linear Berganda

\begin{tabular}{|l|l|l|l|}
\hline No & \multicolumn{1}{|c|}{ Variabel } & \multicolumn{1}{c|}{ Koefisien } & \multicolumn{1}{c|}{ Keterangan } \\
\hline 1 & (Constan) & 7,915 & - \\
\hline 2 & Pertumbuhan Ekonomi $\left(\mathrm{X}_{1}\right)$ & 0,167 & Ha diterima \\
\hline 3 & Pengeluaran Pemerintah $\left(\mathrm{X}_{2}\right)$ & 0,442 & Ha diterima \\
\hline 4 & Inflasi $\left(\mathrm{X}_{3}\right)$ & $-0,197$ & Ha diterima \\
\hline $\mathrm{R}=98,9 \% \mathrm{R}-\mathrm{Sq}=97,8 \%$ & \multicolumn{2}{l}{} \\
\hline
\end{tabular}

Sumber: Data diolah tahun 2018

Berdasarkan Tabel 6 dapat dibuat regresi linear berganda sebagai berikut:

$\mathbf{Y}=\mathbf{a}+\mathbf{b}_{1} \mathbf{X}_{1}+\mathbf{b}_{2} \mathbf{X}_{2}+\mathbf{b}_{3} \mathbf{X}_{3}$

$Y=7,915+0,167 X_{1}+0,442 X_{2}-0,197 X_{3}$

Tabel 6 memperlihatkan bahwa pengaruh Pertumbuhan Ekonomi $\left(\mathrm{X}_{1}\right)$ terhadap investasi (Y) adalah positif, dengan koefisien regresinya adalah 0,167. Hal ini berarti jika Pertumbuhan Ekonomi ditingkatkan maka jumlah produiksi $26 \mid$ Novera Martilova, Amsah Hendri Doni akan meningkat sebesar 0,167 atau 16,7 persen. Jadi, semakin besar Pertumbuhan Ekonomi yang terjadi di Provinsi Sumatera Barat akan meningkatkan jumlah investasi, dengan asumsi cateris paribus.

Pengaruh jumlah Pengeluaran Pemerintah $\left(\mathrm{X}_{2}\right)$ terhadap jumlah investasi $(\mathrm{Y})$ adalah positif, dengan koefisien regresinya adalah 0,442 persen. Maksudnya adalah jika jumlah Pengeluaran 
Pemerintah ditingkatkan maka jumlah investasi akan menurun sebesar 0,442 atau 44,2 persen. Hal ini berarti bahwa semakin banyakanggaran atau dana yang dikeluarkan oleh pemerintah provinsi Sumatera Barat baik untuk pengeluaran rutin maupun tidak rutin akan meningkatkan jumlah investasi, dengan asumsi cateris paribus.

Pengaruh jumlah inflasi $\left(\mathrm{X}_{3}\right)$ terhadap jumlah investasi $(\mathrm{Y})$ adalah negatif, dengan koefisien regresinya adalah -0,197 persen. Maksudnya adalah jika jumlah inflasi ditingkatkan maka jumlah investasi akan menurun sebesar 0,197 atau 19,7persen. Hal ini berarti bahwa semakin tinggitingkat inflasi yang terjadi di provinsi Sumatera Barat akan menyebabkan permintaan barang oleh masyarakat akan menurun sehingga masyarakat lebih cenderung untuk menabungkan uangnya di Bank dan berdampak pada jumlah Investasi yang akan dilakukan oleh masyarakat menjadi menurun, dengan asumsi cateris paribus.
Berdasarkan hasil persamaan regresi di atas diketahui bahwa apabila Pertumbuhan Ekonomi, Pengeluaran Pemerintah dan inflasi tidak mempengaruhi Investasi atau dianggap konstan maka Investasi bernilai sebesar nilai konstanta yaitu sebesar 7.915 persen. Dengan demikian dapat disimpulkan bahwa jumlah Investasi di propinsi Sumatera Barat tidak hanya ditentukan oleh Pertumbuhan Ekonomi, Pengeluaran Pemerintah dan inflasi tetapi ada juga variabel lain yang tidak diteliti.

\section{Koefisien Determinasi $\left(R^{2}\right)$}

Nilai Investasi dengan Pertumbuhan Ekonomi, Pengeluaran Pemerintah dan inflasi secara umum (R) adalah sebesar 98,9 persen. Kemudian koefisien determinasi (R-Square) adalah sebesar 97,8 persen. Sedangkan sisanya 2,2 persen Investasi di Propinsi Sumatera Barat dipengaruhi oleh faktor lain yang tidak diteliti.

Tabel 6. Koefisien Determinasi $\left(R^{2}\right)$

\begin{tabular}{|c|l|l|}
\hline Model & \multicolumn{1}{|c|}{ R } & \multicolumn{1}{c|}{ R Square } \\
\hline Pertumbuhan Ekonomi, Pengeluaran Pemerintah dan Inflasi & 0.989 & 0.978 \\
\hline
\end{tabular}

Sumber: Data diolah tahun 2018

\section{Pengujian Hipotesis}

Untuk membuktikan pengaruh masingmasing Pertumbuhan Ekonomi $\left(\mathrm{X}_{1}\right)$, Pengeluaran
Pemerintah $\left(\mathrm{X}_{2}\right)$, dan inflasi $\left(\mathrm{X}_{3}\right)$ terhadap investasi digunakan tabel coefisients sebagai berikut:

Tabel 7. Hasil Uji t

\begin{tabular}{|l|l|l|l|l|}
\hline No & \multicolumn{1}{|c|}{ Variabel } & \multicolumn{1}{c|}{ Nilai $t_{\text {hitung }}$} & \multicolumn{1}{c|}{ Sig } & \multicolumn{1}{c|}{ Ket } \\
\hline 1 & Pertumbuhan Ekonomi $\left(\mathrm{X}_{1}\right)$ & 6,670 & 0,000 & Signifikan \\
\hline 2 & Pengeluaran Pemerintah $\left(\mathrm{X}_{2}\right)$ & 2,712 & 0,020 & Signifikan \\
\hline 3 & Inflasi $\left(\mathrm{X}_{3}\right)$ & 2,239 & 0,027 & Signifikan \\
\hline
\end{tabular}

Sumber: Data diolah tahun 2018

Uji ini digunakan untuk membuktikan pengaruh masing-masing variabel bebas terhadap variabel terikat.

\section{Hipotesis 1}

Hipotesis 1 pada penelitian ini ialah adanya pengaruh signifikan antara antara Pertumbuhan Analisis Pengaruh Pertumbuhan Ekonomi... || 27 
Ekonomi $\left(\mathrm{X}_{1}\right)$ terhadap jumlah Investasi $(\mathrm{Y})$ di Propinsi Sumatera Barat.

Berdasarkan hasil olahan data yang disajikan pada Tabel 8 dapat dilihat hasil uji t, diperoleh nilai thit $>$ t tabel yaitu 6,670 $>2,13$ atau diperoleh nilai Sig $<\alpha(0,000<0,05)$ akibatnya Ho di tolak dan Ha diterima. Sehingga hipotesis alternatif yang diajukan dalam penelitian ini diterima bahwa terdapat pengaruh yang signifikan antara Pertumbuhan Ekonomi $\left(\mathrm{X}_{1}\right)$ terhadap jumlah Investasi di Propinsi Sumatera Barat.

\section{Hipotesis 2}

Hipotesis 2 pada penelitian ini ialah Pengeluaran Pemerintah $\left(\mathrm{X}_{2}\right)$ memiliki pengaruh signifikan terhadap terhadap jumlah Investasi (Y) di Propinsi Sumatera Barat.

Berdasarkan hasil olahan data yang disajikan pada Tabel 8 dapat dilihat hasil uji t, diperoleh nilai $\mathrm{t}$ hit $>\mathrm{t}$ tabel yaitu 2,713 $>2,13$ atau diperoleh nilai $\operatorname{Sig}<\alpha(0,020<0,05)$ akibatnya Ho di tolak dan Ha diterima. Jadi, hipotesis alternatif yang diajukan pada penelitian ini dapat diterima. Terdapat pengaruh yang signifikan antara Pengeluaran Pemerintah $\left(\mathrm{X}_{2}\right)$ terhadap jumlah Investasi ( $Y$ ) di Propinsi Sumatera Barat.

\section{Hipotesis 3}

Hipotesis 3 pada penelitian ini ialah inflasi $\left(\mathrm{X}_{3}\right)$ memiliki pengaruh signifikan terhadap jumlah Investasi $(Y)$ di Propinsi Sumatera Barat. Berdasarkan hasil olahan data yang disajikan pada Tabel 8 dapat dilihat hasil uji $\mathrm{t}$, diperoleh nilai $\mathrm{t}$ hit $>t$ tabel yaitu 2,239 $>2,13$ atau diperoleh nilai Sig $<\alpha(0,027<0,05)$ akibatnya Ho di tolak dan Ha diterima. Jadi dapat diketahui bahwa hipotesis alternatif yang diajukan pada penelitian ini dapat diterima, artinya terdapat pengaruh yang signifikan antara inflasi $\left(\mathrm{X}_{3}\right)$ terhadap jumlah Investasi $(Y)$ di Propinsi Sumatera Barat.

Tabel 8. Hasil Uji F

\begin{tabular}{|l|l|l|l|l|l|l|}
\hline Model & Sum Of square & Df & Mean square & F & Sig & Keterangan \\
\hline Regression & 1165.513 & 3 & 388.50 & 16.563 & $.000^{\mathrm{a}}$ & $\mathrm{H}_{0}$ ditolak \\
\hline Residual & 258.011 & 11 & 23.455 & & & $\mathrm{H}_{\mathrm{a}}$ diterima \\
\hline Total & 374.524 & 14 & & & & \\
\hline
\end{tabular}

Sumber: Data diolah tahun 2018

Hipotesis ini menjelaskan bahwa Pertumbuhan Ekonomi, Pengeluaran Pemerintah dan inflasi secara simultan berpengaruh terhadap jumlah Investasi di Propinsi Sumatera Barat.

Pada analisis ini hipotesis diuji dengan menggunakan uji F. Jika F hitung lebih besar dari F tabel, maka hipotesis nol (Ho) ditolak dan hipotesis alternatif ( $\mathrm{Ha}$ ) diterima. Jadi dapat disimpulkan bahwa variabel bebas berpengaruh terhadap variabel terikat secara simultan. Di bawah ini disajikan Tabel analisis varian (ANOVA).

28 | Novera Martilova, Amsah Hendri Doni
Dalam pengujian ini diperoleh nilai signifikan yang diperoleh adalah $\mathrm{F}_{\text {hitung }}>\mathrm{F}_{\text {tabel }}$ yaitu 16,563 $>3,59$ atau nilai sig $<\alpha$ yaitu $0,000<0,05$. Hal ini menjelaskan bahwa $\mathrm{H}_{\mathrm{o}}$ ditolak dan $\mathrm{H}_{\mathrm{a}}$ diterima, sehingga hipotesis yang diajukan dalam penelitian ini terbukti diterima, dimana jumlah Pertumbuhan Ekonomi, Pengeluaran Pemerintah dan inflasi berpengaruh signifikan terhadap jumlah Investasi secara simultan. 


\section{PENUTUP}

Berdasarkan hasil penelitian dan pembahasan, maka kesimpulan yang dapat diperoleh adalah:

1. Pertumbuhan Ekonomi memiliki pengaruh signifikan terhadap Investasi di Sumatera Barat. Hal ini dapat dilihat dari hasil olahan data diperoleh nilai $t$ hit $>\mathrm{t}$ tabel yaitu 6,670 $>2,13$ atau diperoleh nilai Sig $<\alpha(0,000<$ $0,05)$ akibatnya Ho di tolak dan Ha diterima. Sehingga hipotesis alternatif yang diajukan pada penelitian ini diterima.

2. Pengeluaran Pemerintah mempengaruhi investasi di Sumatera Barat secara signifikan. Hal ini dapat dilihat dari hasil olahan data diperoleh nilai $\mathrm{t}$ hit $>\mathrm{t}$ tabel yaitu 2,713 > 2,13 atau diperoleh nilai Sig $<\alpha(0,020<$ $0,05)$ akibatnya Ho di tolak dan Ha diterima. Sehingga hipotesis alternatif yang diajukan pada penelitian ini diterima.

3. Inflasi memiliki pengaruh signifikan terhadap Investasi di Sumatera Barat. Ha ini dapat dilihat dari hasil olahan data diperoleh nilai $t$ hit $>t$ tabel yaitu 2,239 > 2,13 atau diperoleh nilai Sig $<\alpha(0,027<0,05)$ akibatnya Ho di tolak dan Ha diterima. Sehingga hipotesis alternatif yang diajukan dalam penelitian ini dapat diterima.

4. Secara Simultan Pertumbuhan Ekonomi, Pengeluaran Pemerintah dan Inflasi memiliki pengaruh signifikan terhadap Investasi di Sumatera Barat. Hal ini dapat dilihat dari hasil olahan data diperoleh nilai Dalam pengujian ini diperoleh nilai signifikan yang diperoleh adalah $\mathrm{F}_{\text {hitung }}>\mathrm{F}_{\text {tabel }}$ yaitu 16,563 $>3,59$ atau nilai sig $<\alpha$ yaitu $0,000<0,05$.
Hal ini menjelaskan bahwa $\mathrm{H}_{\mathrm{o}}$ ditolak dan $\mathrm{H}_{\mathrm{a}}$ diterima, sehingga hipotesis yang diajukan dalam penelitian ini terbukti diterima.

\section{DAFTAR KEPUSTAKAAN}

Abdul, Halim. 2005. Analisis Investasi. Edisi Kedua. Jakarta: Salemba Empat

Arsyad, Lincoln. 2010. Ekonomi Pembangunan. Yogyakarta: UPP STIM YKPN

Badan Pusat Statistik. 2017. Sumatera Barat Dalam Angka. Padang: BPS Sumbar

Boediono. 1999. Teori Pertumbuhan Ekonomi, Seri Sinopsis, Pengantar Ilmu Ekonomi No. 4, Edisi Pertama, Cetakan Keenam, BPFE, Yogyakarta

Dornbusch, Rudlqer, dkk. 2004. Makro Ekonomi. Edisi Bahasa Indonesia. Jakarta: PT. Media Global Edukasi

Dumairy. 1999. Perekonomian Indonesia. Jakarta: Erlangga

Eko Prasety, P. 2011. Fundamental Makro Ekonomi. Yogyakarta: BETA Offset

Fadhillah. G. A. 2014. Analisis Pengaruh Pajak Daerah, Retribusi Daerah, Dan Pendapatan Lain-Lain Terhadap Pertumbuhan Ekonomi di Kabupaten Jember Dalam Era otonomi Daerah. Jember: Universitas Jember

Gunawan. 2007. Ekonometrika Pengantar. BPFE: Yogyakarta

Gujarati, Damodar (Terjemahan Sumarso Zein). 2004. Ekonometrika Dasar. Jakarta: Erlangga

HS, Salim. 2008. Hukum Investasi di Indonesia. Jakarta: Raja Grafindo Persada

Analisis Pengaruh Pertumbuhan Ekonomi... | 29 
JURNAL IMARA

Jhingan, 2001.Ekonomi Pembangunan dan Perencanaan, Jakarta: Rajawali Press.

Makmun, Akhmad Yasin. 2003. Pengaruh Investasi dan Tenaga Kerja Terhadap PDB sektor Pertanian, Kajian Ekonomi dan Keuangan, Vol.7, No.3 : 63.

Mangkosoebroto, Guritno. 1996. Ekonomi Publik, Edisi Ketiga, Yogyakarta: BPFE.

Mankiw, N. Greorgy. 2007. Teori Makro Ekonomi. Edisi Keempat. Alih Bahasa: Imam Nurmawam. Jakarta : Erlangga.

Nanga, Muana. 2005. Makro Ekonomi : Teori Masalah dan Kebijakan. Jakarta : PT Raja Grafindo Persada.

Nopirin.2000. Pengantar Ilmu Ekonomi Makro \& Mikro, Yogyakarta: BPFE-Yogyakarta.

Rahardja, Prathama. 2014. Teori Ekonomi Makro. Jakarta:Lembaga Penerbit Fakultas Ekonomi Universitas Indonesia.

Salvatore. 1997. Ekonomi Internasional. Jakarta : Erlangga.

Samuelson, Paul A dan William D. Nordhaus. 2004. Ekonomi. Jakarta: Erlangga.

Sukirno, Sadono. 2010. Makroekonomi Teori Pengantar. Jakarta: PT Raja Grafindo Persada.
Sarwedi.2005. Investasi Langsung Di Indoesia Dan Faktor Yang Mempengaruhinya. Jember: Universitas jember.

Soejaiz, Z. 2003. Good Governance Dan Daya Saing Investasi Global. Jurnal ilmu Sosial dan ilmu politik (volum 6nomor 3, maret 2013, 309328). Jakarta.

Soemodiharjo,I.H. 1999. Pengantar Ekonometri. Jember: Universitas Jember.

Sunariyah. 2004. Pengantar Pengetahuan Pasar Modal. Edisi Keempat. Yogyakarta: UPP AMP YKPN.

Tambunan, Tulus T. H. 2003. Perekonomian Indonesia: Teori dan Temuan Empiris, Ghalia Indonesia, Jakarta.

Wijayanti, P. 2011. Pengaruh Ketersediaan Tenaga Kerja, Infrastuktur, Pendapatan Perkapita Dan Suku Bunga Terhadap Investasi Industri Kota Semarang. Skripsi.Semarang: Universitas Diponegoro.

Winardi,1992. Kamus Ekonomi: Inggris-Indonesia, Bandung: Alumni, 1992.

30 || Novera Martilova, Amsah Hendri Doni 